\title{
Truth and Reconciliation in South Africa: the role of the faith communities
}

\author{
P G J Meiring \\ University of Pretoria
}

\section{ABSTRACT \\ Truth and Reconciliation in South Africa: the role of the faith communities}

Ten years after the South African Truth and Reconciliation Commission commenced with its work (1995), the author - using the statements made by representatives of the different faith communities in South Africa-analyses the role the communities played in the past: as agents of oppression, as victims of apartheid, as opponents of apartheid, as well as their role in the country's transition to a new democratic society. Finally, the contribution of the faith communities in the process of reconciliation and nation building is discussed.

\section{INTRODUCTION}

"Probably the best of all the Truth Commission hearings", Archbishop Desmond Tutu declared at the conclusion of the hearing in East London (Eastern Cape, 17-19 November 1997). Tutu's colleagues agreed: the special Hearing for Faith Communities, called by the South African Truth and Reconciliation Commission (TRC), was indeed one of the highlights of the TRC's programme (Meiring 1999:65; cf Boraine 200:179ff; Tutu 1998:177ff) For four days religious leaders, congregants, delegates from many countries and human rights specialists met to evaluate the role of the faith communities in South Africa during the apartheid era, and to discuss the contribution that these communities may bring in the process of national reconciliation. The hall was packed, and journalists saw to it that news of the proceedings reached audiences all over the world.

The TRC was instituted by an act of Parliament in July 1995 exactly ten years ago - with the mandate to establish a complete picture of the apartheid past, to facilitate the granting of amnesty to perpetrators of gross human rights violations, and to grant the opportunity to victims of these violations to relate their own accounts 
of the violations they suffered, and to recommend reparation measures in this respect. Finally, the TRC was required to report on its findings, with recommendations of measures to prevent future violations of human rights in the country (TRC Report 1988, Vol 1:148ff) .

During the course of its work the TRC's Committee on Gross Human Rights Violations invited thousands of victims as well as perpetrators from many communities - political leaders, security force personnel, military officers, and activists guilty of various violations to submit their statements at 140 hearings held in many parts of the country. With that finished, the TRC requested representatives of special interest groups - the medical fraternity, lawyers, the media, big business, academic institutions, political parties, the police and correctional services, women's groups, the youth - to do the same. The very last of these 'special hearings' was devoted to the South African faith communities. The event was held in the port city of East London, the venue where 17 months earlier the first of the TRC victims' hearings took place.

The invitation to the religious leaders in South Africa to attend the hearing was preceded by a serious debate within the ranks of the TRC. A number of commissioners questioned the wisdom of having such a hearing at all. Surely the faith communities - even the Afrikaans Churches who for many years publicly supported the policy of apartheid - were not guilty of gross human rights violations?

What would they confess to? But, countered the rest of the commissioners, the churches as well as the other faith communities were so closely involved in everything that happened in South Africa, on both sides of the struggle, that it was inconceivable not to invite them to address the TRC. The pastors and the priests, the bishops and the moderators, the imams and the rabbi's needed an opportunity to tell their stories: stories of guilt and shame, of pain and suffering, also stories of courage and conviction, of forgiveness and reconciliation (TRC Report 1998, Vol 4:59).

In total, forty-one faith communities made written submissions or gave representations at the hearing. While some churches (among them the Evangelical Lutheran Church, the Nederduitsch Hervormde Kerk and the Gereformeerde Kerke) chose not to accept the invitation, the 
leaders of the South African Council of Churches, the main line Protestant Churches, the Roman Catholic Church, as well as of Pentecostal, Charismatic and African Initiated Churches (AICs) were present in full force, sharing the podium with the Chief Rabbi of South Africa, representatives of the Ramakrishna Institute of Spirituality and Hinduism, the South African Hindu Maha Sabha, The Jamaitul Ulama Transvaal, the Muslim Judicial Council, the Call of Islam, the Buddhist Dharma Centre, as well as with spokespersons of the Bahai' Faith (TRC Report 1998, Vol 4:60). Each of the representatives was asked to address primarily four questions: To what extent has the community suffered under apartheid? Were there some in the community that overtly or covertly supported the racist policies of the past? Was the community - or some in the community - involved in the struggle against apartheid? Lastly, what contribution may be expected from the community in the process of nation building and reconciliation?

\section{THE SOUTH AFRICAN FAITH COMMUNITY}

Although often regarded as a "Christian country", South Africa is indeed a land of many religions. Christians are in the majority (74,1 percent of the population, according to the 1996 National Census), followed by Muslims (1,4 percent), Hindus (1,3 percent), and Jews (0,2 percent). Small communities of Buddhists, Baha'is, and other religions are also to be found. Relatively few Africans, according to census results, saw themselves as belonging to African Traditional Religion, although the influence of traditional religion is strongly felt in many (Black) church communities (cf Hendriks \& Erasmus 2002:13ff.)

When placed alongside the more highly organized religions listed in the paragraphs below, African Traditional Religion is at a significant disadvantage. Often dismissed as 'culture' rather than 'religion', African Traditional Religion over the years lacked centralized and acknowledged leadership and regulatory bodies to give it identity. It is often represented by black Christian theologians rather than by traditional religious leaders themselves. African Traditional Religion nevertheless represents what the TRC Report on the Faith Communities Hearing called " a vibrant cluster of practices that are part of the lives of many Africans, including those who attend Christian Churches” (TRC Report, Vol 4:61, cf Meiring 1996:1ff). 
Although Roman Catholicism arrived in South Africa with the coming of the Portuguese explorers at the end of the 15th century, Christianity was established predominantly in Protestant denominations. The Dutch Reformed Church that arrived with Jan van Riebeeck (1652) was, for virtually one an a half century regarded as the only religio licita in the country, although Moravian missionaries were allowed, from 1737, to spread the Gospel among the indigenous Khoi and San people. Since the British occupation of the Cape (1806) other Protestant denominations - Anglicans, Methodists, Presbyterians, Congregationalists, Lutherans - as well as missionaries from many overseas countries, made their entrance on the scene. By the mid $19^{\text {th }}$ century the Roman Catholic Church had established itself firmly in South Africa. Pentecostal churches and Charismatic churches are relatively new comers to South Africa, but have grown dramatically during the latter half of the $20^{\text {th }}$ century. A very significant development was the emergence of a number of African Initiated Churches (AICs) who, over more than a hundred years, endeavoring to present the Gospel "in the cloak of Africa", drawing millions of Black Christians to their side. Most of the mainline churches belong to the S A Council of Churches (SACC), while a number of evangelical denominations are tied to The Evangelical Alliance of Southern Africa (TEASA) (TRC Report 1998, Vol 4:61ff).

Muslims arrived in South Africa virtually simultaneously with the Dutch colonists who settled in the Cape in the middle of the $17^{\text {th }}$ century. Shortly after Van Riebeeck's arrival Muslim slaves were offloaded in Table Bay, to be followed by the Mardyckers who came from Ambonya in the Moluccas, as well as a number of Muslim exiles. In the second half of the $19^{\text {th }}$ century Indians were brought to Natal by the British, to work in the sugar fields of the colony. Among these indentured labourers were Muslims. Many of them, in later years, established themselves in the trade and business community. The Muslim Judicial Council was founded in 1945 to promote unity among South African Muslims. Despite the efforts of Imam Abdullah Haron who was killed in 1969 the MJC took an apolitical stance for many years. The emergence of the Muslim Youth Movement, Qibla, and Call of Islam in the aftermath of the 
Soweto uprising (1976) created a strong social and political consciousness amongst Muslims (TRC Report 1998, Vol 4:63f, cf Meiring 1996:149).

It was only in 1806 with the English occupation that the Jewish community, too, was welcomed to this part of Africa, and were able to organize their religious institutions. With the discovery of diamonds in Kimberley (1867) and gold (Transvaal, 1873) a substantial number of of immigrants from Anglo-German and Lithuanian origins arrived in the country. The Jewish Board of Deputies (formed in 1912) as well as the S A Zionist Federation (1898) are the community's two representative bodies. The vast influence of the Jewish community in every sphere of life in South Africa has often been acclaimed: in trade and industry, in education, law, academe, culture and sports. In recent years however, the number of Jews has dwindled to 68060 (according to the National Census of 1996). Those who have stayed behind, are as active as ever in the community (TRC Report 1998, Vol 4:64, cf Meiring 1996:96ff).

The first Hindus to make South Africa their home arrived in South Africa as Indian immigrant labourers assigned to work in the sugar industry (November 1860). After the term of their indenture ended, many of them stayed on as farmers - despite government's attempts to repatriate Indians in the 1920 . At the end of the $19^{\text {th }}$ century a second group of immigrants, the so-called "passenger Indians' who were able to pay their own fare to Natal, also arrived. They set up trade and industry businesses, initially in Natal but later throughout the country. Indians in South Africa are a very diverse community with four major language groups, each with its distinctive worship practices, religious rites, customs and dress. The various Hindu communities and religious institutions are represented by one over arching body, the Hindu Maha Sabha (established in 1912) (TRC Report 1998, Vol 4:64, cf Meiring 1996:27ff).

The Buddhist community in South Africa is relatively small. While some are of Indian origin, most South African Buddhists are white devotees, who in recent years found themselves attracted to the faith. There are no centralized Buddhist structures in the country, but a number of small organisations and centers serve the community. The 
first Buddhist Society was formed in Natal (1917). The Dharma Centre in Somerset West representing the Zen tradition was inaugurated in 1984. A recent development is the building of a huge Nan Hau Temple complex at Bronkhorstspruit, near Pretoria (TRC Report 1998, Vol4:64f, cf Meiring 1996:67ff)

Members of the Baha'i community have been living in South Africa since 1911. It was, however, only since the 1950s that the Baha'i community started to organize itself, and to extend an influence in the wider community. The community is committed to inclusivity, and has embarked on special drive to promote black leadership within its ranks.

\section{FAITH COMMUNITIES AS AGENTS OF OPPRESSION}

The first issue the representatives of the different faith communities were asked to address, was the role that institutions, or individual members, played to promote or to uphold the racist policies and structures of the past. To what extend did the community overtly or covertly supported apartheid? Merely asking this question of communities that according to their own ethos and creeds existed to promote justice, peace and reconciliation, the TRC Report stated, seemed contradictory. In most cases, faith communities claimed to cut across divisions of race, gender, class and ethnicity. As such, they would seem by their very existence to have been in opposition to the policies of the apartheid state and, in pursuing their own norms and values, to have constituted a direct challenge to apartheid policies. However, contrary to their own deepest principles, many faith communities mirrored apartheid society, giving lie to their profession of a loyalty that transcended social divisions (TRC Report 1998, Vol 4:65)

\subsection{Acts of commission}

At the East London hearing there was great interest in the submission that the Rev Freek Swanepoel, moderator of the Dutch Reformed Church - the church that did not only condone apartheid, but over many years provided a theological argument for the policy of 'separate development' - would make. Although the DRC never saw itself as the 'State Church', many did regard the DRC as the 'government at prayer', harbouring many of "the willing executioners of apartheid" 
within its ranks. When Swanepoel took the stand he brought with him a confession adopted by the General Synod of the DRC three years earlier that stated that its support of apartheid was sinful and heretical. The Church, he said, owed a heartfelt apology to fellow South Africans who were hurt by the DRC's stance, to the wider faith community in the country, as well as to its own members who over may years were led astray (Meiring 1999:270ff). Entering into the spirit of the hearing other Christian denominations who did not officially sanction apartheid, also confessed actions and practices that from time to time belied their official statements. Acts of commission, according to the TRC's findings, took different forms:

\subsubsection{Participating in state structures}

The appointment of military chaplains was of great concern to many. Not only Afrikaans churches supplied military chaplains, but chaplains were also appointed from the ranks of the Anglican, Methodist, Presbyterian, Baptist, Apostolic Faith Mission and Roman Catholic Churches. Whatever the motivation of the chaplains - who wanted to provide pastoral care to congregants serving in the defense force - their participation served to "reinforce the acceptance of the apartheid cause in the minds of church members, and often justified the the 'demonisation' of their opponents” (TRC Report 1988, Vol 4:67).

Other state structures, too,were served by members of the Christian churches. The Apostolic Faith Mission reported that a large number of its members were employed in government structures, many holding senior positions in former apartheid organizations. The Reformed Presbyterian Church told of its members who took part in homeland structures in the 1960's, defending the Bantustan policies and the right of the state to suppress "unlawful subversion" (Report 1998, Vol 4:66). Mention was also made of individuals as well as groups within the Muslim community who - some for idealistic, other for practical reasons - chose to collaborate with the regime. When the government introduced the South African Indian Council, the Coloured Representative Council and subsequently (in 1984) the Tri-Cameral System, some Muslims decided to participate. This lead to violent recriminations between Muslims in many parts of the country, causing rifts that to this day have not completely healed. There were also cases of Hindu leaders who worked with the apartheid regime, although the 
Hindu community's submission to the TRC made only passing reference to the fact (Bham 1997:285; Meiring 2004a:5).

\subsubsection{Suppressing and censuring dissidents}

Some faith communities confessed that not only did they fail to give sufficient support to anti-apartheid activists in their midst, but that they suppressed, censured and condemned dissidents, even to the point of branding them as 'heretics'. A case in point is that of the Rev Frank Chikane (the then Secretary General of the S A Council of Churches and a leader of the Black section of the AFM) who was tortured under the supervision of a white elder of his own denomination who after the event, went of to worship (TRC Report, Vol 4:68). The DRC confessed that it treated its own members - Ben Marais, Bennie Keet, Beyers Naudé, David Bosch, and others - who repeatedly warned against apartheid, badly.

Whilst Chief Rabbi Harris did not elaborate on the Jewish community's support of apartheid as well as on the failure of South African Jews to speak out against racism in the country, an important publication of interviews with a number of Jewish leaders, published while the TRC was conducting its business, voiced strong criticism. The Jewish Board of Deputies - who only took a grudging antiapartheid stance late in the day - was often uncomfortable with the actions of activists and labour movement leaders in their midst. After 1990, Ronnie Kasrils remarked in his interview, it has become fashionable to identify with the pioneers and prophets of the past: "The Jewish community has lionized these individuals to some extent now that it is kosher to do so, but in the past many of them were condemned as people who were bringing notoriety to the community" (Suttner 1997:280).

\subsubsection{Internalising racism}

Despite their claim to loyalties that transcend the state, South African churches, whether implicitly or as a matter of policy, allowed themselves to be structured along racial lines, "reinforcing the separate symbolic universes in which South Africans lived" (TRC Report, Vol 4:68). Besides the Afrikaans Churches, the Apostolic Faith Mission, the Lutheran Church as well as the Seventh Day Adventist Church was racially divided. Conservative-evangelical organizations followed suit. 
Even churches that adhered to the principle of non-racism in their structures, were not without guilt in their everyday practice. The Salvation Army confessed to tacit support of racism. The Roman Catholic Church, looking back in history, stated that "effectively there was a black church and a white church". It was equally true of the English speaking churches, where Sunday morning and evening worship services "constituted the most segregated hours of the week". Black leaders were not sufficiently empowered to take their rightful positions in the church. Stipends were drastically different for black and white clergy, reinforcing racial stereotypes of lifestyle differences. "The same contradictions that are prevalent in society are present and often reflected in the life of the church" the Rev James Buys, moderator of the Uniting Reformed Church, told the hearing (Buys 1997:146f, TRC Report 1998, Vol 4:69).

Discrimination was also prevalent in the non-Christian faith communities. Imam Rashid Omar of the Claremont Mosque, Cape Town, reported to the TRC that theological distinctions between Indian and Malay Muslims reflected ethno-class distinctions, as exemplified in the Ulamas and the Cape Muslim organization respectively (TRC Report 1998, Vol 4:69).

\subsubsection{Propagating 'state theology'}

A serious charge against not only the Afrikaans Churches, but against a number of conservative-evangelical and Pentecostal denominations was the propagation of 'state theology'. The term was coined by the 'Kairos' theologians who, in a document published in 1985, accused some South African churches of propagating a theology that gave legitimacy to the apartheid state. The effects of state theology were to "bless injustice, canonize the will of the powerful and reduce the poor to passivity, obedience and apathy” (Kairos Document 1985:17). Moss Nthla, general secretary of The Evangelical Alliance of South Africa, acknowledged that Evangelical Churches often played in the hands of government agencies by "neutralizing dissent", and by encouraging their congregants to refrain from "meddling in politics". Some Apostolic Faith Mission pastors taught that opposition to apartheid was "Communist-inspired and aimed at the downfall of Christianity". Others admitted to promoting state theology by persuading their congregants that it was in the interests of "Christian civilization" to 
support the state's “total onslaught” strategy (TRC Report 1998, Vol 4:70).

\subsection{Acts of omission}

Acts of omission, according to the TRC Report, revolved around three things: an unwillingness to accept responsibility, the failure to act, and the failure to support members who were involved in anti-apartheid activities.

\subsubsection{Avoiding responsibility}

Looking back into the past virtually all the religious groupings expressed regret at their failure to speak out effectively against injustice. They had a moral obligation to serve as a conscience to the nation, but for a variety of reasons did not protest loud enough and effective enough to make a difference in the country. For the Roman Catholic Church this was perhaps the church's greatest sin. Even the Uniting Reformed Church who over many years have been consistent in its opposition against apartheid, confessed to "taking too long to make a stand, particularly against the migrant labour system. Such a failure indicated 'silent approval' of state actions" (Buys 1997:138ff; TRC Report 1998, Vol 4:73).

Faried Essack accused the Muslim leadership of being guilty of the same failure, as did Ashwin Trikamjee of the Hindu Maha Sabha. The unwillingness of Hindu leaders to speak and to act against apartheid created the idea that Hindus were part of the system. The community itself was at fault too, Trikamjee argued. They should have removed the "irresponsible" leaders from office (Trikamjee, 1987:289ff). Chief Rabbi Harris also acknowledged the fact that many leaders in the Jewish community did not make themselves heard strongly enough to make a difference (Harris 1997:269). Dr Franz Auerbach, speaking for the World Conference of Religion and Peace which through the years coordinated inter-faith actions against apartheid, wryly commented on leaders "who were only reluctantly drawn into the struggle. They came kicking and screaming and often did not go beyond adding their signatures to a diluted anti-apartheid statement” (Auerbach:216).

One reason for not accepting responsibility, was simply a lack of courage. Representatives of the Church of England, the Catholic 
Church, the Presbyterian Church, even the (Black) African Initiated Churches admitted that they should have acted more courageously, but that they refrained from doing so, sometimes for fear of putting themselves at risk, at other times for fear of alienating their flock especially their wealthier congregants whose financial interests were at stake. The Catholic Church cited its precarious position as "the Roomse gevaar" ("Roman danger") in a predominantly Protestant country, as reason for its initial reluctance to act.

Explaining why the Jewish community was often reluctant to oppose the apartheid regime, Rabbi Harris pointed out that the Jewish community was very small, consisting of immigrants in a foreign country, often feeling very insecure about their own position. The trauma of the holocaust and the fear of anti-Semitism within the ruling National Party, made them fearful to give any impression that they were against the state (Harris 1997:269). The seasoned politician Helen Suzman thought the reaction of many of her fellow Jews to be far too timid: "I thought that the Jewish Board of Deputies should have spoken up more against apartheid. Of course they have changed over the last ten years, and became very much outspoken in their condemnation. Prior to that I think they were just dead scared to bring Jews under the beady eye of people like Dr Verwoerd, who were outspokenly antiSemitic” (Suttner 1997:431).

In the Muslim community, too, the refusal of the leaders of the Jamaitul Ulama Transvaal to speak out against apartheid, was severely criticized by Imam Solomon and Faried Esack. The Transvaal leaders simply lost their nerve."They obstinately refused to be moved from their record of silence on any political issues which would appear to be anti-state" (Solomon 1997:292).

\subsubsection{Failure to act}

It was not only the failure to speak, but the failure to act, that compromised the faith communities' position. Many communities who took strong decisions against apartheid, found it very difficult to translate their resolutions into practical action. James Buys of the Uniting Reformed Church emphasized that this was far greater than a logistical problem. Such failures represented "a blatant omission and silent approval of the conditions and main cause of human rights 
violations” (Buys 1997:143). One of the most moving confessions of guilt in this respect was from Beyers Naudé and Nico Smith, two stalwarts in the struggle against apartheid. Their "Open Letter" was, prior the hearing, circulated in church circles and co-signed by a large number of pastors. Most South Africans were amazed: Oom Bey, of all people - the man who had suffered so much because of his fight against apartheid! "I have not done enough", Naudé said. "How is it possible that our preaching was so ineffective, that our actions were so timid, that we did so little to ease the pain of the victims, to confront the rulers of the country, the exponents of the ideology of apartheid?” (Meiring 1999:115).

\subsubsection{Failure to support anti-apartheid activists}

The failure of the faith communities to the activities of members who spoke out against injustice, or who worked to bring an end to the apartheid regime, was mentioned in many submissions. The Dutch Reformed Church confessed that it treated the "prophets within its midst" shoddily. The Church of the Province apologized to Archbishop Tutu for its failure to support his call for economic sanctions against the former regime. The Baptist Union was accused by the Baptist Convention of refusing to acknowledge Baptist activists who were detained at Robben Island prison. In a similar vein the Jewish Board of Deputies was blamed for not supporting - but strongly criticizing rabbis who spoke out against apartheid (Harris 1997:270; Suttner 1997:616). Farid Esack, speaking on behalf of the Call of Islam castigated the Muslim leadership on their "thundering silence" after the death in detention of Abdullah Haron in 1969 (Meiring 1999:265ff).

Not only individuals suffered for lack of support from their peers. Institutions, too, that were engaged in anti-apartheid activities and had the apparent verbal support of faith communities, were often left unsupported. A case in point was the Christian Institute of South Africa that was declared an 'affected organisation' by the Schlebush Commission and thus prevented from receiving external funds (1975). "Little or no material support came from those churches that had verbally supported it in synods and assemblies", the TRC was told. "When it was banned two years later, along with its executive leadership, little action was taken and little support given to many of 
those who were affected” (TRC Report 1998, Vol 4:75, cf Naudé 1995:109ff).

\section{FAITH COMMUNITIES AS VICTIMS OF OPPRESSION}

To what extend did the faith community suffer under apartheid?, representatives appearing before the hearing were asked. The various answers given may be summarized under three headings:

\subsection{Direct attacks by the state on members and organizations}

From time to time members as well as institutions of the different faith communities suffered from direct attacks by the apartheid state. Numerous examples were given.

The banning of the Christian Institute in 1977, and the subsequent house arrest of its director Beyers Naudé received attention. The "ongoing battle" between the government and the S A Council of Churches waged on a number of fronts - through media disinformation, the appointment of the Eloff Commission, security raids, the arrest and torture of staff members, culminating in the bombing of Khotso House, headquarters of the SACC in 1988. Six weeks later the headquarters of the S A Catholic Bishops' Conference were destroyed by arsonists, and Father Smangeliso Mhkatshwa, General Sectretary, was detained and tortured. In its submission the Church of the Province mentioned Father Michael Lapsley who lost both his arms and an eye in a parcel bomb attack in 1990 (two months after the unbanning of the liberation movements) as "a living icon of redemptive suffering within the church” (TRC Report 1998, Vol 4:76).

In his submission Joshi made a similar reference to Hindu leaders, Monty Naicker, Nana Sita, J N Singh and others, who over the years suffered, were imprisoned, and died, for their resistance against apartheid (Joshi 1997:351ff). Moulana Bham brought homage to Muslim activists who, like Abdullah Haron, were detained, imprisoned, tortured, banned, exiled, and in some cases killed (Bham 1997:248). The Jewish community, Harris pointed out, produced proportionally more heroes of the struggle than any other so-called white group. Some were imprisoned, some went into exile, some were martyred such as Ruth First, and some others almost martyred, such as Albie Sachs (Harris 1997:270). 


\subsection{The closure of buildings, institutions and schools}

Inevitably, faith communities were affected by the notorious Group Areas Act. Congregations were often forced to leave 'white areas', to relocate to the proper 'group area'. Historic buildings like the London Missionary Society Church in Graaf Reinet (built in 1802) and the stone church in Majeng in the Nortern Cape (built in 1874 and bulldozed in 1975) were lost in the process. The Moravian Church lost numerous buildings in Port Elizabeth and Cape Town. Congregations were often forced to sell their properties at low prices, hindering their efforts to re-establish their congregations after removal. The Bantu Education Act forced the closure of numerous mission stations and mission schools, some with long traditions of service to the community. The Methodists lost Healdtown and Kilnerton; the United Congregational Church Adams College and Tiger Kloof; and the Reformed Presyterian Church Lovedale and Blytheswood. Several submissions refered to the closing of the Federal Theological Seminary in Alice. A number of mission hospitals were also affected (TRC Report 1998, Vol 4:76ff).

For the Muslim community the loss of a mosque was especially painful. More than a building, the Muslin Judicial Council Submission explained, a mosque is regarded as a sacred site and must never be abandoned. Group Areas legislation was a direct attack on this principle, assuming that the sacrality of such spaces was transferable to wherever the state decided to resettle the community. Sometimes the Muslim community's vehement protests carried the day, but in most cases mosques as well as land used for prayer were desecrated (Bham 1997:284).

The Hindu community suffered equally, Trikamjee reported. For more than sixty years the life of the Indian community has been seriously affected by the periodic introduction of laws governing land tenure. Each new enactment deprived the people of existing property rights, radically reducing the areas in which Indian occupation and ownership was permitted. The most serious and painful legislation was the Group Areas Act of 1950. Settled communities were uprooted and relocated, having to abandon schools and temples they have built for themselves with great care over the years. In Cato Manor (Durban) Indians suffered great hardships because of the act. Institutions for 
children and disabled people were lost. In Johannesburg temples, schools, and cultural centres were left behind. Family life as well as communal life were severely harmed. To compound the problem, Trikamjee reported, religious sites set apart by city planners in the new Indian areas were generally purchased by Christian churches who had access to the necessary funds. This has lead to many conversions to other faiths, especially to Christianity (Trikamjee:289ff).

\subsection{The repression of religious and cultural values}

Despite the fact that South Africans adhere to many different religions, the apartheid state saw itself as a guardian of “Christian civilisation”. Christian National Education was imposed on non-Christian communities, much to the chagrin of Hindu and Muslim parents and religious leaders who feared that their religious values in education were repressed, and alien values imposed. Muslim children were indoctrinated into "a Christian National philosophy which denigrated an Islamic perspective of life", Moulana Bham told the TRC (Bham 1997:284). This also happened in Christian communities, such as the Ibandla amaNazaretha where children were forced to remove their hair, dishonouring taboos concerning shaving, causing ritual defilement (TRC Report, 1998, Vol 4:77).

A second cause of concern was the repression of religious law, especially in the case of Hinduism and Islam. "In the legal system of the day", Moulana Bham explained, "Muslim personal and family law was not recognized. Muslim marriages were not legally valid, resulting in children being considered illegitimate or born out of wedlock" (284). The Muslim Youth Movement pointed out that the state sometimes tried to use religious laws to suit its own ends. In 1986 the Ulamas were co-opted onto a South African Law Commission committee to draft legislation on the recognition of Muslim marriages. The MYM called it "a cynical attempt on the part of the state to gain the approval of the Islamic community" - an attempt that was thwarted by the MYM who pressured the Muslim leaders to withdraw (TRC Report, 1998, Vol 4:77).

Hindu cultural life, too, was disrupted. Contact with the motherland, India, was difficult, also because of the cultural boycott instituted by the Indian government against South Africa in protest 
against the apartheid policy of the National Party - a boycott that lasted the better part of fifty years. "Up till recently we were not allowed to invite religious scholars or cultural artists to promote these values. Family members from India were not allowed to visit us. Furthermore...Hindu marriages were not recognized and were considered to be illegitimate! We could not use seating facilities in restaurants, and had to stand outside and eat our food for which we paid the same price. We were regularly insulted by Whites, at the least provocation. The legal system was practiced on double standards. The darker the skin colour, the stricter the punishment. Such were some of the atrocities” (Joshi 1997:352ff).

The religious values of the Baha'i faith preclude opposition to the state, a position that is often contested by other communities. It put them in a precarious position. Because of their racially mixed worship and black leadership, they were often under government surveillance. In the eyes of some in the black activists the "Black Baha'is" were seen as traitors. This resulted in the tragic execution of four black Baha' is in Umtata and Mdantsane (TRC Report, 1998, Vol 4:77).

The situation was often compounded by the fact that some Christians, often under the influence of state propaganda, played their part in victimizing other religious communities, distorting their values and creating caricatures. In extreme cases, Bham reported, Muslim places of worship were attacked or desecrated by unknown persons, allegedly right wingers who saw Islam as a threat to Christianity” (Bham 1997:284).

\section{FAITH COMMUNITIES AS OPPONENTS OF APART- HEID}

Answering the third question on the involvement of the faith communities in the struggle was complicated. What did "opposition against apartheid" entail? For the leadership of the Zion Christian Church, instilling pride and teaching their black congregants to stand up straight in their own institutions was a strong repudiation of the treatment of their members in apartheid South Africa. For the Hindu Maha Sabha passive resistance, following in the footsteps of Mahathma Gandhi, was the answer. The Church of England and the Afrikaans churches mentioned private meetings with government officials. For 
the SACC the watershed came when it began to identify itself with the liberation movements. In its Report on the Faith Communities Hearing the TRC chose to speak of a "continuum of opposition" which takes into account positions taken by the faith communities before as well as after the Soweto uprising in 1976.

\subsection{Alternative institutions}

For more than a century black Christians expressed protest against white domination by creating separate black institutions, under black control, using black cultural resources. The African Initiated Churches (AICs) were mainly concerned with the creation of an alternative to white churches, but were from the start deemed by the authorities as a possible political threat, destabilising the state's grasp on the hearts and minds of its subjects. The Zion Christian Church and the Ibandla amaNazaretha strongly argued that instilling pride and moral discipline among their members was a very effective way of opposition (TRC Report, 1998, Vol 4:79ff).

\subsection{Petitions and private appeals}

Many churches and other faith communities reported on their petitions to government, as the preferred way of expressing opposition to apartheid. The Church of England in South Africa, as well as the Afrikaans Churches used this method, stating that public opposition was often counterproductive. Private discussions on various issues were held, but, the Dutch Reformed Church admitted, seldom to call the apartheid policies in question, asking only that they should be applied "with compassion and humanity". The Baha'i leaders, positioning themselves as "politically neutral", chose to meet officials in private as well, to discuss matters of concern to them (TRC Report, 1998, Vol $4: 80 f)$.

\subsection{Official statements and resolutions}

Throughout the years many official statements were published by the faith communities, to express their misgivings. Numerous statements and resolutions were discussed at the hearing. Special attention was given to the important statements coming from the ranks of the Christian churches: the Cottesloe Statement (1960), the SACC's Message to the People (1968), the Resolution on Conscientious Objection and the Resolution on Non-Cooperation that urged Christians 
to withdraw from state structures (1974), the Kairos Document (1985), the "Ope Brief" (Open Letter) by 123 Dutch Reformed Church theologians, as well as the Belhar Confession, the first Christian confession to produced on South African soil (Report 81-84).

Theological resistance was not limited to the Christian Churches. Shortly after the Cottesloe Statement the Muslim Youth Movement, the Muslim Judicial Council, together with other Muslim organizations, produced "The Call of Islam Declaration" (1961). "For too long a time now we have been, together with our fellow-sufferers, subjugated, suffered humiliation of being regarded as inferior beings, deprived of our basic rights to earn, to learn and to worship according to the Divine Rule of Allah. We can no longer tolerate further encroachment on these, our basic rights, and therefore we stand firm with our brothers in fighting the evil monster that is about to devour us - that is oppression, tyranny and baasskap (supremacy)" (Solomon:289). The publication of the Declaration was followed by a packed meeting in the Cape Town city hall (7 May 1961), where the MJC solemnly declared that "apartheid in any form can not be condoned by Islam" In 1964 a national conference called by the Muslim Judicial Council protested against the Group Areas Act, admonishing Muslim that under no circumstances, mosques should be abandoned. In the 1980s Muslim leaders participated in the United Democratic Front's 'Don't Vote' campaign, arguing that a vote for the Tricameral Parliament was haraam (prohibited).

\subsection{Withdrawing from state structures}

One of the most effective acts of opposition was withdrawal from state structures. In the Christian community a serious debate developed on whether Christians should be involved in the military. Some churches the Seventh Day Adventists and the Quakers - objected to military service per se, while some clergy and congregants from other churches were unwilling to serve in an apartheid army, fighting to defend an unjust system. Actions taken against conscientious objectors were often severe. The SACC and its member churches who launched its End of Conscription Campaign, did their best to support objectors. Some churches, out of pastoral concern for members who served in the armed forces, decided - albeit reluctantly - to keep their chaplains. Other denominations - the Presbyterian Church and the United 
Congregational Church - decided to meet with representatives of the liberation movements, to discuss the possibility of appointing chaplains to their armies (TRC Report, 1998, Vol 4:85).

In the Coloured and Indian communities resistance to cooperating with state structures reached boiling point with the installation of the Tricameral Parliament. Although every effort was made to co-opt Muslim, Hindu and Christian leaders into the system - and although some were willing to do that - there was a strong consensus in the two communities that becoming part of an apartheid structure was unacceptable. Opposition in the Hindu community was admittedly not unanimous: 20 percent of the community did go to the polls to vote for their representatives in the new parliament (Joshi 1997:352). In the Muslim community, however, it was "contrary to the spirit of Islam". Partaking in the new parliament became an issue in Christian churches within the Coloured community as well. The United Congregational Church urged its members to distance themselves from the Tricameral Parliament and removed participants as Rev Alasn Hendrikse and Rev Andrew Julies - two former chairs of the church - from their ministers' role.

\subsection{Civil disobedience and passive resistance}

A fourth way of expressing opposition to the apartheid government was by deliberately disobeying state laws. In the Hindu community, a long tradition of civil disobedience existed. It was never easy, P Joshi explained in his submission. For Hindus who regarded all forms of life as being endowed with the Supreme Spirit, resisting apartheid, joining the struggling did not come naturally. While Hindus were strongly opposed to any form of discrimination, they are equally opposed to any form of violence against any living being, Joshi stated in the preamble of his submission (Joshi 1997:351). In the early years of the twentieth century Mahatma Gandhi, who spent 21 years in South Africa, provided an answer to the Indian community.

In the eyes of thousands of Indians, Gandhi personified the attempt of practicing Hinduism in daily life - the very essence of the message of the Bhagavad Gita. The foundations of the practice of this philosophy of Satya-Graha (non-violent non-cooperation) found root in the very soil that we are born and living - South Africa (Joshi 
1997:351). But this philosophy also created conflict in the minds of dedicated Hindus: How do we oppose the tyranny of racial discrimination? Through armed retaliation? Through non-co-operation? "This ideal", Joshi concluded, "was manifested in general in the Hindu response: non-violent non-cooperation. It is also an ages-old Hindu tenet that one should learn to love your enemy, who may enslave your body, but never your mind and spirit” (Joshi 1997:351). Many Hindus in Natal and Transvaal joined the First Massive Resistance Campaign of 1906 to 1914, launched by Gandhi soon after his arrival as a lawyer in South Africa. They shared in the imprisonment and hardships of their leader (Gandhi 1927:272ff, cf Trikamjee:299f). Four decades later the Second Passive Resistance Campaign followed when thousands of Indians protested against the passing of the Pegging Act (1943) and the Asiatic Land Tenure Act (1946) when more than 2000 men and women who resisted passively were taken to jail. In recent years other leaders have taken up the cause of civil disobedience - among whom Nana Sita, president of the Transvaal Indian Congress, who despite his advanced age and acute arthritis served his term in jail.

In the Christian community civil disobedience became an issue many years later, when the Presbyterian Church embarked upon a campaign of defying laws on mixed marriages, group areas, deliberately quoting banned persons and publications. The Catholic Church decided to open its schools to all races in 1976, sparking a dispute with government that would last until 1991. Other communities, Muslim as well as Baha'i, flouted apartheid laws by promoting mixed worship and study sessions.

\subsection{Solidarity with liberation movements}

After 1976 when the struggle against apartheid intensified, the faith communities were increasingly faced with the dilemma: should they show solidarity with the liberation movements? Most of the churches chose a middle way, preferring not to lend full support to either the liberation movements or the state. But after Soweto, and especially after the launch of the United Democratic Front (1983), several denominations realized that they had to take sides. Contact with the liberation movements in exile was maintained throughout the 1980s. The interfaith Conference on World Religion and Peace met with ANC 
leaders in Zambia to discus the role of religion in a post-apartheid South Africa (TRC Report, 1998, Vol 4:87).

The Catholic Church mobilized its own structures and opened parish halls to popular organizations to hold meetings, aiding and assisting activists in many ways. When the activities of die UDF and COSATU were severely restricted, faith community leaders began to fill important leadership roles, solidifying the relationship between the faith communities and the liberation movements. A bone of contention during these years were the support - or lack of support - of churches for economic sanctions against the government. Many church leaders opposed sanctions, or were ambivalent on the issue. The Church of the Province, despite Archbishop Tutu's repeated requests, only belatedly (in 1989) decided to support sanctions. The Catholic Church "fearing a great increase of poverty and unemployment" supported sanctions with reservations (TRC Report, 1998, Vol 4:87).

\section{THE FAITH COMMUNITIES ROLE IN SOUTH AFRICA'S TRANSITION}

The role of the faith communities did not end with the unbanning of the liberation movements in 1990. Much still had to be done to prepare South Africans for the transition that was to come, and the faith communities were called upon in numerous ways to play their part. Muslim organizations joined in a national conference as negotiations between the National Part government and the liberation movements got underway. The World Council of Religion and Peace held an interfaith conference called 'Believers in the Future' to discuss religious rights and responsibilities in the new South Africa. The SACC and the SA Catholic Bishops Conference joined the liberation movements in a National Coordinating Committee for the Repatriation of South African Exiles in 1991. A number of Churches and Christian organizations met at Rustenburg to discuss their future responsibilities. Confessions from participants at Rustenburg anticipated those made at TRC hearings. In 1991 the National Peace Accord was launched in September 1991, again with heavy involvement from the SACC and its member churches. Catholics and Protestants worked together to prepare South Africans for the coming elections, with numerous voter education programs. The Church Leaders Forum, representing a wide collection of denominations, met with political leaders, to urge them on 
the path of a negotiated setllement. When the Conference on a Democratic South Africa (CODESA) broke down the church leaders worked hard, sometimes behind the scene, to restart the negotiations. And when the elections came, the WCRP, the SACC and the SACBC formed a Panel of Religious Leaders for Electoral Justice, to monitor the electoral process.

This does not mean to say, the TRC Report concluded, that all denominations and Christians were equally committed to the transformation of the country. It was often individual leaders who shouldered the responsibility, while many were hesitant to enter the fray.

\section{AGENTS OF RECONCILIATION?}

What is the specific contribution that the faith communities can offer in terms of healing, reconciliation and nation building?, was the final question put before the bishop, pastors, imams and priests. Each of them used the opportunity to discuss their community's role in this regard. There were high expectations. All future healing processes and reconciliation efforts deeply depended upon the role that Christians, Jews, Muslims, Hindus, African traditionalists, and the rest, are willing to play, Tutu emphasized. "Religion is central to the process of healing", the Archbishop wrote six months into the life of the TRC. "We need to reach the deep spiritual wells of our different religious traditions...to draw strength and grace with which to address the challenges of healing and nation building (Botman \& Petersen 1996:8).

\subsection{The role of religion}

Not all South Africans - and definitely not all TRC commissioners were overly enthusiastic about the role that religion was allowed to play in the truth and reconciliation process. The way that Tutu facilitated the proceedings, raised questions. The TRC process was a legal process, it was said, and should be conducted in a juridical style. Tutu arriving at most hearings wearing his archbishop's vestments, opening and closing each day with a hymn and a prayer, was unacceptable. The Archbishop, however, maintained that when issues of guilt and forgiveness, reconciliation and healing - each of them loaded with religious beliefs and experiences - are at stake, one cannot but allow religion to play its part (Meiring 2000:13f). Criticism, too, was also leveled at the 
"Christianization" of the TRC process. "It contributed significantly to Muslims remaining on the sidelines", Faried Esack told a post TRC conference in Holland. "On the day of my testimony I spoke critically of the symbolism of having Jews, Muslims and Hindus coming to testify to an all-Christian panel, headed by an archbishop sitting under a huge crucifix in a church hall' (Esack 2002:296) (Author's note: Esack was mistaken. Ms Yasmin Sooka, a Hindu, sat in the panel).

\subsection{Privileged position of Christians}

Another obstacle on the road to reconciliation, was the privileged position of the Christian churches in South Africa. To strive towards reconciliation is a wonderful ideal, Rabbi Harris explained, but it should never be taken for granted. Christians had it easy in the past. There were in the majority. But being a member of one of the 'minority religions' in a South Africa that considered itself to be a 'Christian country', was not always easy. Understanding one another, accepting one another, working towards healing and reconciliation may take time.

If we talk of the past, we should not only think of apartheid, security legislation and all those things, Essack added. Christian 'triumphalism' was also an issue. In an avowed 'Christian state' adherents of other faiths often ran into difficulties. "If you were a Muslim - somebody who was part of the so-called 'Muslim threat' you were often regarded as an enemy of the state and treated as such". It was ironic that as recently as 1986, the year when the Dutch Reformed Church has for the first time started to take leave of apartheid, the General Synod still referred to Islam as a "false religion" (Meiring 1999:272).

Desmond Tutu was aware of the hurt. Looking at the audience and into the television cameras, he solemnly declared: "I am certain that all my fellow Christians in South Africa will agree with me if I express our deep apologies to you, the members of the other faith communities in the country, for the arrogant way in we as Christians acted - as though ours was the only religion in South Africa, while we have been a multi-religious community from day one" (Meiring 1999:272). 


\subsection{Answering the challenge}

In spite of all this, the TRC expressed its fervent hope that the faith communities will take up the challenge of healing and reconciliation. If the religious leaders and their flock fail to reach out to one another, to build bridges across the many divides in the country, who would? In the TRC's Final Report six specific challenges to the faith communities were made (TRC Report V, 1998:316ff):

- to seek ways to communicate with one another as a basis for eliminating religious conflict and promoting inter-religious understanding;

- to seek ways to incorporate marginalized groups into their communities;

- to promote a culture of tolerance and peaceful co-existence;

- to inspire their members to work together in a peace corps to help communities in need;

- to organise reconciliation ceremonies, creating liturgies to heal and to celebrate the reconciliation that we do experience in the country;

- and, finally, to develop theologies designed to promote reconciliation and a true sense of community in the nation.

At the East London hearing all the representatives of the different communities categorically stated their commitment to work together for the healing and reconciliation, nation building. It would be a costly process, they agreed. But the willingness to reach out to one another was apparent. There was a willingness, too, to share the guilt of the past. It was not only members from the Afrikaans speaking churches who harboured negative feelings against Muslims, Rashied Omar maintained. Members of most Christian denominations were as guilty. Actually, the imam said, none of us should be pointing a finger. All of us, Christians, Muslims, Hindus and Jews harboured among us individuals who acted questionably towards one another, who were guilty of collaborating with the apartheid regime, often to the disadvantage of the liberation struggle. "For the sake of rebuilding our country spiritually it is vitally important that we as religious leaders, 
get our people to confess their complicity in apartheid and racism" (Meiring 1999:273).

P Joshi, speaking for the Hindu community also entered into the spirit of reconciliation. In his concluding remarks to the hearing he said: "There is a lot... to be done, a lot of issues...to be addressed, before we can call ourselves non-racial, democratic, etc. We need to change our spirit truthfully, sincerely wishing to make change, and not only seeking our own advantage. If we want true healing to occur, we must stop talking of our hurt only. Let us forgive” (Joshi 1997:354, cf Chapman \& Spong 2003:260).

Geof Siffrin, speaking for Gesher (Jewish Movement for Social Action) expressed similar sentiments. Forgiveness does not necessary come easy, but without forgiving those who harmed you, you can never truly be free: For reconciliation to happen, people have to face each other. The offended party must be willing to offer forgiveness. Forgiveness does not mean that we accept or accommodate the evil that has been perpetrated. Rather, without in any way condoning the act, forgiveness is the ability to let go of the resentment towards the person responsible. It you don't do that, you are not free. There still is a lot of resentment in South Africa today. Virtually all sections of society harbour these resentments. Victims as well as perpetrators are crippled by their resentments. In order to move towards reconciliation, Gesher called upon all South Africans, as a national priority, to explore ways to help people to understand one another's resentments, and to find ways of getting rid of these feelings, so that we can be free to build a healthy, strong society (Gesher 1997:279).

Working together on practical issues to incorporate the marginalized in society, to promote a culture of tolerance, to create structures to address the needs of the destitute, even to organize religious ceremonies, creating liturgies for healing and reconciliation according the the TRC's challenges - would not create problems. It has been happening, and will continue to happen.

Meeting one another on a theological level, entering into as serious dialogue on the foundational truths and convictions of the different faiths - and how these truths and convictions impact on the joint process of healing and reconciliation - may prove to be more 
difficult. But it can and should be done. Already in the TRC submissions, as well as in a number of subsequent publications, perspectives have been offered on how Christians, Muslims, Jews, Hindus, Buddhists, and African Traditionalists, may learn from another and compliment one another in this regard (cf. Meiring 2003; 2004a; 2004b). Of course there are differences that need to be respected, but in the words of Beyers Naudé, one of the 'grand old men' of the struggle, taken from his autobiography written just as the TRC was commencing with its work: The issue at stake is not the extent of our differences, but the where and how we can work together (Naudé 1995:143).

\section{8 "IT SEEMS TO HAVE WORKED..."}

Tutu adjudged the Faith Community Hearing in East London as "probably the best of all TRC hearings". Many others were in agreement (Boraine 2000:179ff; Meiring 1999:265) Contrary to the expectations of critics, it did serve a purpose, bringing important insights and information - sometimes painful and shocking, at other times humbling and encouraging - to the fore. Moreover, the hearing helped to guide the faith communities on their journey into the future. As to the role of religion within the TRC process, the last word belongs to Jorge Heine, Chilean ambassador to South Africa. When the TRC finally closed its doors and presented its Final Report to President Nelson Mandela, Heine observed: "Sitting at the hearings held at the Central Methodist Church in downtown Johannesburg some time ago, watching archbishop Desmond Tutu say a prayer...I could not help but reflect that this would have been unthinkable in many countries where the separation of church and state is taken seriously. Yet is seems to have worked in South Africa, where there is a great religious diversity but where the strongly Christian subtext of repentance and forgiveness that pervades the Commissions proceedings conveys both the right message as to what is reconciliation all about. It manages to put at ease humble, profoundly decent South Africans who had been offered, often for the first time, the opportunity to state their case" (The Sunday Independent, 2 August 1998).

Tutu's words at the handing over ceremony - attended inter alia by a fair number of religious leaders who have testified at the Faith Communities hearing - reverberated in many hearts: "We have been wounded, but we are being healed. It is possible even with our past 
suffering, anguish, alienation and violence to become one people, reconciled, healed, caring, compassionate and ready to share as we put our past behind us to stride into the glorious future God holds before us as the Rainbow People of God” (Meiring 1999:379).

\section{Consulted literature}

Boraine, A 2000. A country unmasked. Oxford: Oxford University Press

Botman, H R and Peterson, R M 1996. To remember and to heal. Cape Town: Human and Rousseau

Chapman, A and Song B (ed) 2003. Religion and Reconciliation in South Africa. Philadelphia/London: Templeton.

Esack, F 2002. An Islamic view of conflict and reconciliation in the South African situation”, in: Gort, J (et al). Religion, conflict and reconciliation. AmsterdamNew York: Rudopi.

Ghandi, M K 1927. An autobiography - or the story of my experiments with truth. Ahmedabad: Navajivan Publishing House.

Hendriks, J and Erasmus J 2002. "A general statistical picture of religion in South Africa” in: Kritzinger, J J. No quick fixes. Pretoria: ISWEN

Kairos Theologians 1985. Challenging the Church. The Kairos Document. Grand Rapids: Eerdmans

Meiring, P (ed) 1996. A world of Religions. A South African Perspective. Pretoria: Kagiso

-, 1999. Chronicle of the Truth Commission. Vanderbijlpark: Carpe Diem.

-, 2000. The baruti vs the lawyers: the role of religion in the TRC process in: Villa-Vicencio, C (ed). Looking back. Reaching forward. Cape Town: University of Cape Town Press

-, 2003. "The Muslim voice in South Africa - in the era of Truth and Reconciliation” in NGTT 44(3/4), 393-406.

-, 2004a: "Truth and Reconciliation in South Africa. Hindu experiences" in HTS 60(4), 1383-1398.

-, 2004b. "Truth and Reconciliation in South Africa. Jewish Voices and Perspectives' in Verbum et Ecclesia 25(2), 546-561.

Naude, B 1995. My land van hoop. Kaapstad: Human en Rousseau.Cape Town: Nederduitse Gereformeerde Kerk 1997: Die verhaal van die $N$ G Kerk se reis met Apartheid. Wellington: Hugenote-uitgewers. 
South African Truth and Reconciliation Commission 1997: Faith Commission Hearings Agenda (The page numbers in the text refer to the TRC Programme):

Auerbach, F. Submission by the World Conference on Religion and Peace. (South Africa).

Bham, E I. Submission by the Jamiatul Ulama - Transvaal.

Buys, J. Submission by the Uniting Reformed Church of $S$ A.

Dawood, N. Submission by the Muslim Youth Movement.

Gesher (Jewish Movement for Social Action): Reconciliation - a Jewish View.

Harris, C. Submission by the Jewish Religious Community.

Hone, B. Submission by the Baha'i National Office.

Joshi, P. Submission by the President of the Ramakrishna Institute of Spirituality and Hinduism.

Schiff, R. Submission by the Zen Buddhist Dharma Centre.

Solomon, G. Submission by the Muslim Judicial Council.

Swanepoel, F. Submission by the N G Kerk (D R Church).

Trikamjee, A. Submission by the President of the South African Hindu Maha Sabha.

South African Truth and Reconciliation Commission 1998/2003: Report, Volumes 1-5 (1998), Volume 6 (2003). Cape Town: TRC.

Suttner, I (ed) 1997. Cutting through the mountain. interviews with South African Jewisi Activists. London: Viking.

Tutu, D 1998. No future without forgiveness. London: Rider 